Utah State University

DigitalCommons@USU

$11-2011$

\title{
Librarian Perceptions and Information Literacy Instruction Models
}

\author{
Erin Davis \\ Utah State University \\ Kacy Lundstrom \\ Utah State University \\ Pamela N. Martin \\ Utah State University
}

Follow this and additional works at: https://digitalcommons.usu.edu/lib_pubs

Part of the Library and Information Science Commons

\section{Recommended Citation}

Davis, Erin; Lundstrom, Kacy; and Martin, Pamela N., "Librarian Perceptions and Information Literacy Instruction Models" (2011). Library Faculty \& Staff Publications. Paper 106.

https://digitalcommons.usu.edu/lib_pubs/106

This Article is brought to you for free and open access by the Libraries at DigitalCommons@USU. It has been accepted for inclusion in Library Faculty \& Staff Publications by an authorized administrator of DigitalCommons@USU. For more information, please contact digitalcommons@usu.edu.

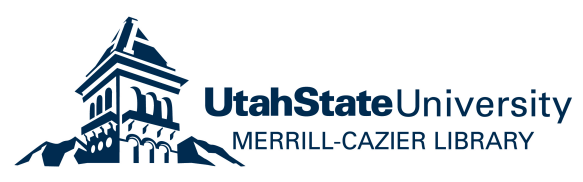




\title{
Librarian Perceptions and Information Literacy Instruction Models
}

\begin{abstract}
Purpose- This paper explores both instruction librarians' attitudes on teaching and how they identify themselves as teachers. Particular attention is paid to teaching librarians' views on the effectiveness of two types of instruction models: for-credit courses and course-integrated library instruction.
\end{abstract}

Design/methodology/approach - To investigate librarians' attitudes towards these two models, a survey was constructed targeting librarians who teach information literacy (IL).

Findings - The results indicate that there is an important relationship between the IL instruction model employed and feelings towards campus politics, perceived effectiveness of IL models, and librarians' self-identification as teachers.

Research limitations/implications - The survey was sent to list-servs whose readership includes high percentages of teaching librarians and received 276 responses. This is by no means an exhaustive study. The research is intended to be exploratory and to delve more deeply than the past editorials and blog posts on the issue of comparing for-credit and course-integrated instruction.

Practical implications - This study can help librarians gain a better understanding of how information literacy models impact librarian perceptions of themselves and their role on campus.

Originality/value - The authors seek to transform a discussion that has occurred mostly informally (in blog posts, on list-servs, and in conversations) into a formal investigation of librarians' attitudes towards the two models.

Keywords - Information literacy; course-integrated instruction; for-credit instruction; credit bearing information literacy; teaching librarians; academic libraries

Paper type - Research paper 


\section{Introduction}

To what degree a librarian serves, or should serve, as a teacher has been debated extensively among academic and librarian communities. Despite this debate, librarians have been teaching for over a century and continue to have an important presence in the classroom (Walter, 2008). The role of librarians as teachers is one many adhere to, but the exact shape of that role has no clear standard. Indeed, librarians' teaching roles can look remarkably different from other teachers', particularly in an academic setting. A number of factors may account for this, but certainly a major consideration is the type of information literacy (IL) model employed by teaching librarians. The two models examined in this study are the course-integrated model and the for-credit model. While both models offer valuable instruction opportunities with students, they also raise interesting questions about teacher effectiveness, the impact on campus, and the challenges and benefits of each. This discussion also considers how librarians believe they are perceived and their perception of support from colleagues and faculty inside and outside the library.

In this study we seek to understand and present the challenges and benefits of both models, while focusing on how the different models used by teaching librarians can affect their views of themselves, the effectiveness of their instruction efforts, and their role in the academic institution. We do not intend to look at librarian self-perceptions simply as a way to understand ourselves as teachers and librarians. Although understanding ourselves and our motivations may be useful, it is secondary to our larger goal, which is to discover the best ways to help students learn. Are we choosing specific models because they really are the best models to promote student learning or are we basing our decisions on institutional support, our own perceptions of our abilities and roles as teachers, or on tradition? These types of questions need to be consistently asked of every instruction opportunity in order to ensure our methods are

pedagogically sound and based on what is best for our students. We suggest that exploring self-perceptions and relating those perceptions to instruction models employed, will provide a new way to question our own methods, both individual and programmatic.

\section{Literature Review}


While both course-integrated and for-credit library instruction have been studied in the literature, little has been done comparing these different models. The literature review analyzes the research that has been conducted on for-credit and course-integrated instruction, including the conversation that has emerged about the two models.

\section{For-CreditLibrary Instruction Literature}

Many studies examine the challenges and benefits of creating for-credit IL courses (see for example MacDonald et al., 2000; Burkhardt, 2007). One of the strongest advocates of forcredit courses is William Badke, who claims "...the rarity of for-credit information literacy instruction in higher education is a disgrace" (2008). The opportunities offered by for-credit courses, such as creating more meaningful relationships, both between librarians and faculty and between librarians and students, have been touted by many researchers. Separate studies by Jane Kemp (2006) and Peggie Partello (2005) reveal deeper relationships with students. Indeed, many authors cite one of the biggest rewards of teaching a credit-bearing course as being the deeper connections made with students and a fuller understanding of their needs due to a more intimate knowledge of their research process (Kemp, 2006; Partello, 2005).

Several authors also write about feelings of being on equal footing with faculty members as a positive result of teaching for-credit courses. They report that librarians gain an understanding of the difficulty of creating clear assignments, and an appreciation for the work faculty do, from grading to handling student crises (Kemp, 2006; Partello, 2005). Nicole Auer and Ellen Krupar argue that for-credit classes help librarians to relate more accurately with faculty and improve interactions between librarians and professors (2005). Gretchen Douglas agrees, stating that teaching for-credit courses provides librarians with a "common experience" with the rest of the faculty and an "increased sensitivity to faculty peers" (1999).

However, not all of the literature about for-credit classes is positive. According to Steven Bell, "the problems come when faculty point to the course and develop a "the librarians teach information literacy in their course so the students learn everything about it there - I don't need to deal with it' mentality" (2008). Trudi Jacobson and Beth Mark also worry about this, arguing "if students do not immediately apply their information literacy skills to a content- 
based course assignment, they tend not to recognize the relevance of such skills to other courses" (2000). Douglas believes librarians, who typically have a 12-month contract, are much more likely to face teaching burnout than professors on a nine-month contract, since librarians don't get the same scheduled breaks as teaching faculty (1999). Additionally, Badke worries that faculty misunderstand credit-bearing IL courses, thinking "we don't need yet another skills course" (2008).

\section{Course-Integrated Library Instruction Literature}

Like for-credit courses, course-integrated instruction has been widely discussed in the literature. Librarians have outlined their approach to teaching course-integrated IL, including the formation of assignments and class exercises (Kobzina, 2010; Bordonaro and Richardson, 2004). Course-integrated instruction is often viewed as an opportunity for meaningful collaboration with teaching faculty, since librarians must work with instructors to create library instruction sessions that suit each class (see for example Lindstrom and Shonrock, 2006; Kobzina, 2010; Bordonaro and Richardson, 2004).

Several authors extoll course-integrated instruction as a model whose embedded nature is its biggest asset. Norma Kobzina discusses the "embedded librarian" concept where librarians "embed" or insert themselves into specific classes throughout the curriculum where students are required to write research papers or do research projects (2010). Joyce Lindstrom and Diana D. Shonrock claim course-integrated instruction allows librarian intervention at a time of need (2006). Bell agrees, applauding course-integrated instruction's "direct relevance to the student's disciplinary work." Bell believes course-integrated IL instruction is effective because it is tailored to the students' assignments, so they can directly apply the research skills they learned that day to their coursework (2008). Diane Zabel points out one of the greatest strengths of course-integrated instruction lies in the fact that students are not required to take unnecessary credits, especially in this economic climate when students' funds are already limited (2004). As Bell argues, "done right, information literacy can be credible - no credits necessary" (2008).

There are, however, some drawbacks to the course-integrated model. Though librarians often laud the opportunities for faculty collaboration that course-integrated instruction can provide, 
others worry that this collaboration will not always be realized. As early as 1998, Marian Winner argued "there is still no widespread acceptance of the librarian's role in curriculum planning and course-integrated instruction" (1998). She claims that while faculty appreciate librarians, they are still not true partners in the classroom. More recently, Laura Saunders surveyed thirteen information literacy experts about the future of IL and the changing role of the librarian. Panelists who saw a collaborative future between faculty and librarians were concerned about "the reticence on the part of faculty that would have to be overcome before a true partnership could be obtained" (Saunders 2008).

\section{For-Credit Literature in Conversation with Course-Integrated Literature}

Few publications in the formal literature address the relationship between for-credit and courseintegrated library instruction. Edward K. Owusu-Ansah envisions a future where IL programs comprised of both course-integrated instruction and for-credit classes are mandated for graduation (2004). Likewise, although MacDonald, Rathemacher and Burkhardt focus on the formation of for-credit courses in their institution, they foresee a future where for-credit courses are supplemented by integration into the curriculum. They want to "provide a concrete way for librarians and other teaching faculty to work together in delivering information literacy skills throughout the curriculum" (2000).

There have been lively discussions of course-integrated and for-credit instruction on the ILILListserv (managed by the Association of College and Research Libraries' (ACRL) Instruction Section) and ACRL blogs. In response to Badke's column, "Ten Reasons to Teach Information Literacy for Credit," Steven Bell countered with an ACRLog blog entry, in which he made a case for course-integrated instruction (2008). Maura Smale, also in a blog entry for ACRLog, admits that there is "debate over whether credit-bearing courses are the best way for academic librarians to advance information literacy" and concludes that "there's no one right way for IL" to be taught (2010).

In summer of 2010, a thread emerged on ILI-L which discussed the virtues, challenges and drawbacks of for-credit and course-integrated instruction. Badke commented: "both embedded [i.e., course-integrated] and separate for-credit courses accomplish significant infolit 
achievement, but there are issues with each that need to be addressed." According to him, embedded programs are most successful when applied to several courses throughout a student's college career and then finalized in a capstone project. This would require institutional support. He argues, "With either option, you will need considerable political will to work with the powers that be" (Badke, 2010).

In conclusion, most of the formal literature approaches these two models separately. This comparative study contributes to the discussion about these two models of library instruction and examines their relationship. This study has the potential to transform a discussion that has occurred mostly informally (in blog posts, on list-servs, and face-to-face, in conversations) into a formal investigation of librarians' attitudes towards the two models.

\section{Methodology}

To explore and compare librarian attitudes towards for-credit and course-integrated library instruction, a survey targeted to librarians who teach IL was constructed. After receiving approval from Utah State University's Institutional Review Board, the survey was sent to listservs whose readership includes high percentages of teaching librarians: ILI-L, the listserv of the Instruction Section; COLLIB-L, the listserv of the College Librarians Section, and STS-L, the listserv of the Science and Technology Section, all sections within the American Library Association. All of these listservs are extremely active electronic discussion lists within sections of the ACRL. The survey was completed by 276 participants.

While this response rate cannot attest to all librarians' experiences, especially as not all institutions are represented from this sample, it can be useful in identifying trends, particularly among active librarians who frequently read listservs such as the ones listed above. This isn't a random sample that mirrors the contours of academic librarianship in terms of years of experience, type of institution. The results cannot be used to draw conclusions because of the nature of this convenience sample. Rather, the research is meant to be exploratory, intended to identify trends worthy of more consideration and research.

The two models of IL that will be discussed from this point on will be referred to as for-credit 
and course-integrated. If a respondent has indicated that they teach both, they will simply be referred to as both. Librarians who only teach one model will be designated only. For the purposes of this study, course-integrated sessions are defined as IL sessions that are tied directly to a course offered through the University and in which library instruction is delivered either as a one-shot or via multiple sessions. For-credit IL courses are defined as courses related specifically to IL, which grant students institutional course credit.

The survey included demographic questions as well as attitudinal and self-perception statements. If participants did not teach IL, they were thanked for their time and exited the survey early. Participants were asked whether they taught only for-credit, only courseintegrated, or both for-credit and course-integrated and were given questions specific to their indications. Librarians who taught only for-credit, both for-credit and course-integrated, and only course-integrated were given slightly different questions designed to fit their teaching experience. To create the attitudinal and self-perception statements, the authors drew on opinions stated in publications, blogs, listserv conversations, and our own personal experience. Participants were asked to rate how much they agreed with the attitudinal and self-perception statements on a five-point Likert scale.

To analyze the results, we looked first for frequency distribution (for example, what percentage of our total respondents strongly agree with the statement, "I consider myself a teacher"?). Results were then cross-tabulated by population type. For example, were there attitudinal differences between librarians at small and big schools? Were librarians more likely to favor their own style of teaching? For this study, the authors looked for the common attitudes among librarians and the variation between populations.

Responses were calculated using percentages, which does not necessarily reflect the varying number of respondents in each category. One hundred eighty respondents taught only courseintegrated, while 78 taught both. Only six respondents taught only for-credit courses. Because so few respondents fell into this category, it was not analyzed and compared alongside the course-integrated group or those who taught both, however those six respondents who taught only for-credit were included in the summative analysis. 


\section{Summary of Findings}

This section reports general, summative findings [see Appendices A-D]. Smaller tables inserted throughout the Discussion section emphasize specific pieces of data. Because some of the data is more meaningful than others, larger, summative tables are included in the appendices and smaller tables have been created and integrated into the text. The primary driver here is to provide clear examples when relevant in the text rather than providing all the data upfront.

The first part of the survey focuses on obtaining demographic and institutional information, mainly to determine what sort of classes are offered by the institution and what type of teaching model the respondent uses. Based on the type of IL model the librarian uses, the respondent was directed to a set of attitudinal and self-perception questions for that group.

The libraries of $55.7 \%$ of respondents do not offer for-credit courses. Of the $36.9 \%$ that do offer it, $11.2 \%$ say for-credit courses are mandatory for their students. Only $8 \%$ of respondents indicate they receive extra compensation for teaching for-credit courses. In comparison, 96.9\% of respondents answered that their institution offers course-integrated IL sessions, and 67.9\% offer general library workshops in which the content is not directly tied to a course, such as citation management workshops. Not surprisingly, an overwhelming number of librarians who teach using either model of IL enjoy teaching. An average of $91.9 \%$ of respondents say they enjoy teaching IL courses, regardless of whether they are course-integrated or for-credit courses.

Out of approximately 245 respondents ${ }^{[1]}$ who answered the "Everyone Answers" section (see Appendix A), 83.3\% agree or strongly agree with the statement, "I consider myself a teacher," and $98.8 \%$ agree or strongly agree with the statement, "I consider myself a librarian." When asked to respond to the question, "I believe students find for-credit information literacy courses more effective than course-integrated information literacy sessions," $58.5 \%$ are neutral, $26.6 \%$ agree or strongly agree, and $15 \%$ disagree or strongly disagree. Similarly, when responding to the statement, "I find for-credit information literacy courses more effective than courseintegrated information literacy sessions," $54.2 \%$ are neutral, $30 \%$ agree or strongly agree and 
15.8\% disagree or strongly disagree. The large neutral response rate, reflected in both of these questions, is likely due to the fact that the respondents who teach only course-integrated were not willing to favor one IL model over the other (see Tables 1-2).

\section{Table 1: For-Credit vs. Course-Integrated}

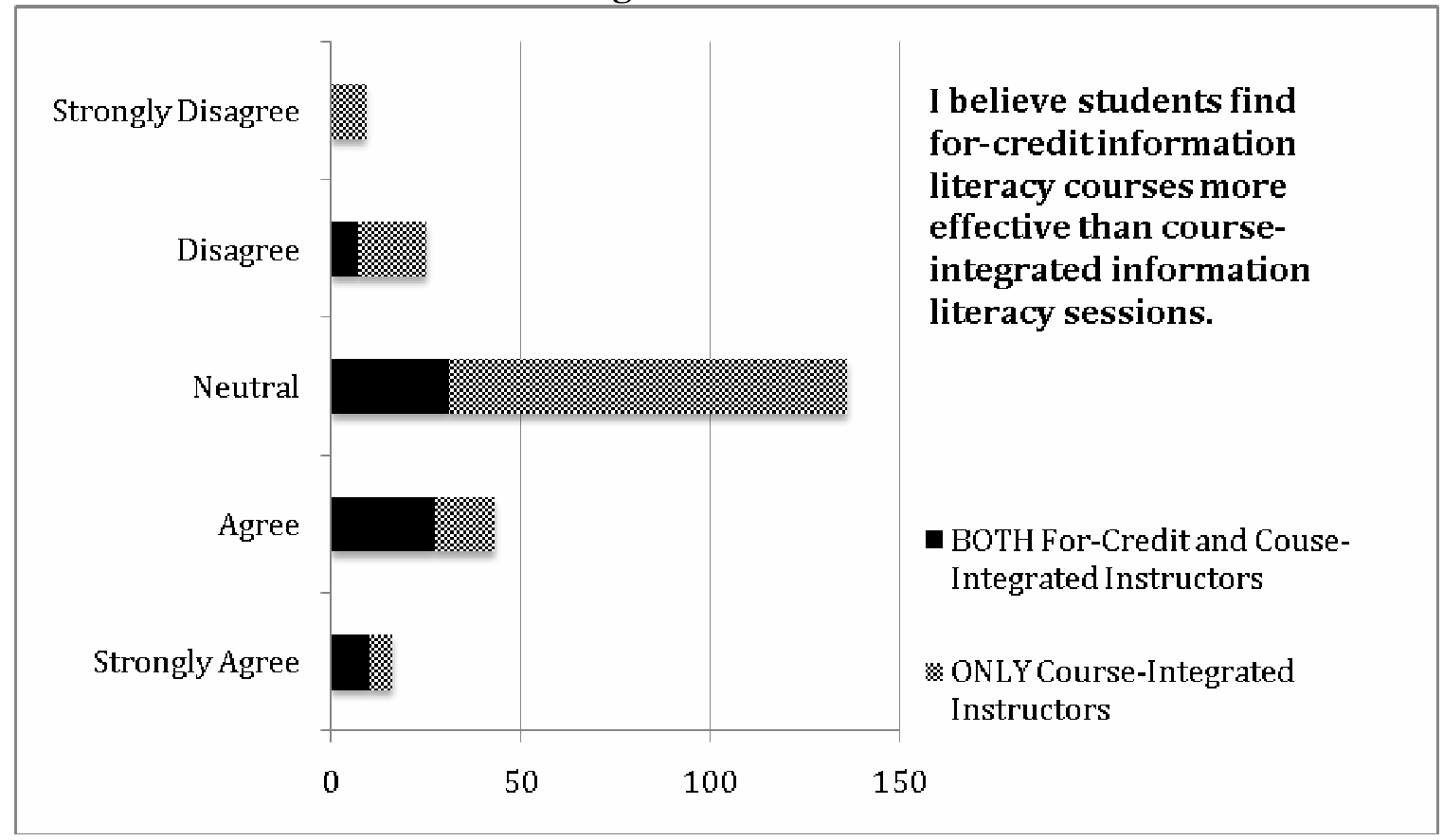

Table 2: For-Credit vs. Course-Integrated

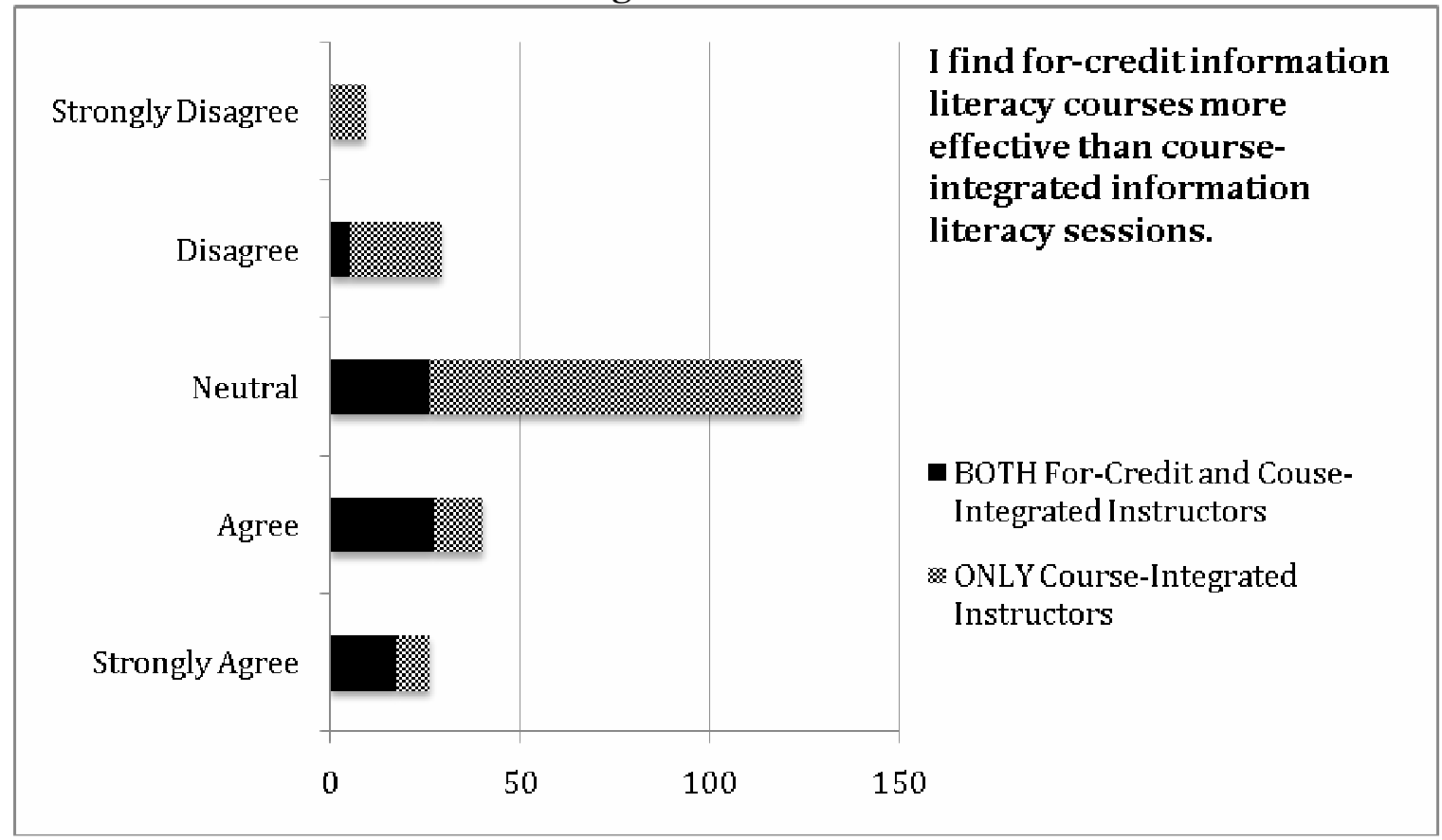


In contrast, $82 \%$ agree with the statement, "The most effective information literacy teaching model integrates instruction throughout students' coursework, preferably beginning with course-integrated information literacy sessions in composition classes and ending with information literacy instruction in capstone courses." These respondents agree with Bell who claims course-integrated sessions are most successful when applied to several courses throughout a student's college career and then culminating in a capstone project (2008).

When asked about library and institutional support, $82.4 \%$ agree or strongly agree with the statement, "I feel supported by library administration in my information literacy teaching endeavors," and $11.1 \%$ disagree or strongly disagree. As for collegial support, $89.3 \%$ agree orstrongly agree that they are supported by their colleagues in their IL teaching endeavors, while only $9 \%$ disagree or strongly disagree. In relation to this, only $56.9 \%$ agree or strongly agree with the statement, "I consider myself as much of a teacher as the professors who teach outside the library," while $23.6 \%$ disagree or strongly disagreewith that same statement.

Overall, these responses hint at some of the other issues raised by this survey, including librarian self-identification as a teacher. While many librarians do identify themselves as teachers, some do not believe they are teachers to the same degree as faculty outside the library. Responses also indicate that librarian beliefs about which instruction model is more effective are related to which models they have experience using. The discrepancy among groups' responses to these and similar issues will be further explored in the Discussion section.

\section{Discussion}

\section{Librarians as Teachers}

According to the survey results, there is an important difference between the model of IL taught and librarians'self-identification as teachers. Of those who teach only course-integrated classes, $77.5 \%$ either agree or strongly agree with the statement "I consider myself a teacher;" $13.1 \%$ of that same group are neutral, and $9.4 \%$ either disagree or strongly disagree with that statement. In contrast, $95.9 \%$ of librarians who teach both for-credit and course-integrated sessions agree or disagree with the statement "I consider myself a teacher." Only $2.7 \%$ responded neutrally and $1.4 \%$ disagree or disagree strongly (see Table 3 ). 


\begin{tabular}{|l|c|c|c|l|l|l|}
\hline $\begin{array}{l}\text { Table 3. Librarians as } \\
\text { Teachers }\end{array}$ & $\boldsymbol{n}$ & $\begin{array}{l}\text { Strongly } \\
\text { Disagree }\end{array}$ & Disagree & Neutral & Agree & $\begin{array}{c}\text { Strongly } \\
\text { Agree }\end{array}$ \\
$\begin{array}{l}\text { Statement: } \\
\text { "I consider myself a } \\
\text { teacher." }\end{array}$ & & & & & & \\
\hline Librarians who teach both & 74 & $0.0 \%$ & $1.4 \%$ & $2.7 \%$ & $43.2 \%$ & $52.7 \%$ \\
\hline $\begin{array}{l}\text { Librarians who teach only } \\
\text { course-integrated }\end{array}$ & 160 & $1.9 \%$ & $7.5 \%$ & $13.1 \%$ & $40.6 \%$ & $36.9 \%$ \\
\hline
\end{tabular}

By extension, when asked to respond to the statement, "I consider myself as much of a teacher as the professors who teach outside the library," there was a similar discrepancy between respondents who teach only course-integrated sessions or both (course-integrated and forcredit). Of those who only teach course-integrated classes, $51.6 \%$ either agree or strongly agree, $18.9 \%$ are neutral, and $29.6 \%$ disagree or strongly disagree. Reflecting a similar disparity to the previously discussed statement, of those who teach both, $70.7 \%$ agree or strongly agree, $17.3 \%$ responded neutrally, while only $12 \%$ disagree or strongly disagree (see Table 4).

\begin{tabular}{|l|l|l|l|l|l|}
\hline Table 4. Librarians as Teachers & $\begin{array}{l}\text { Strongly } \\
\text { Disagree }\end{array}$ & Disagree & Neutral & Agree & $\begin{array}{c}\text { Strongly } \\
\text { Agree }\end{array}$ \\
$\begin{array}{l}\text { Statement: } \\
\text { "I consider myself as much of a } \\
\text { teacher as those who teach } \\
\text { outside the library." }\end{array}$ & & & & & \\
\hline Librarians who teach both & $2.7 \%$ & $9.3 \%$ & $17.3 \%$ & $26.7 \%$ & $44.0 \%$ \\
\hline $\begin{array}{l}\text { Librarians who teach only course- } \\
\text { integrated }\end{array}$ & $5.7 \%$ & $23.9 \%$ & $18.9 \%$ & $27.7 \%$ & $23.9 \%$ \\
\hline
\end{tabular}

The discrepancy between the self-perception of librarians who teach for-credit courses and those who do not is interesting. Both groups overwhelmingly identify themselves as librarians, but those librarians who also teach for-credit coursesare more likely to identify themselves as teachers, even though both groups teach. MacDonald, Rathemacher and Burkhardt assert "Many librarians teach in a classroom setting, though we are not always considered teachers in the traditional sense" (2000). Those who teach for-credit courses may identify more closely with the traditional definition of teaching in academia. This likely relates to the fact that in for- 
credit courses, librarians act as the sole manager of the classroom, performing in a similar role to most teaching faculty outside the library.

Another reason some librarians may not identify themselves as teachers may be related to their job title or status at their campus. Many librarians' professional titles emphasize the aspect of librarianship they perform in their roles but do not identify instruction. Alternatively, some librarians are considered faculty on campus, while others are categorized as being professional staff. The many roles librarians fulfill and their difficulty with maintaining a consistent identity have been widely discussed. According to Stephen E. Atkins, librarianship is devoid of a strong "professional identity" (2003). Another reason some librarians may not identify themselves as teachers could be that the instruction demands of their position are relatively small compared to their other duties. According to one survey respondent, "I do not consider myself a teacher because I also run a small campus library as well as teach information literacy instruction. Although my library colleagues and team leader support my information literacy teaching endeavors, my institution does not. Librarians do not have faculty status at this institution and therefore are not encouraged to take on teaching duties."

Other reasons may be more complicated. Most teaching librarians do not have $\mathrm{PhD}$ 's like teaching faculty on campus. This could cause some librarians to identify less strongly with that role. Faculty member's perceptions of librarians might also affect how librarians see themselves. Most librarians reported feeling supported by their colleagues, but it is unclear as to whether that necessarily applies to other faculty outside the library. Similarly, a survey respondent expressed this same sentiment: "I feel supported by my fellow librarian peers as far as IL teaching endeavors, but not always by professors on campus."

In a recent study, experts found that some faculty fail to view librarians as equals and "assume that they do not have pedagogical knowledge" (Saunders, 2008). At many academic libraries, librarians are among the minority of professionals on campus identified with faculty status but who do not have traditional teaching roles or similar educational backgrounds. Some feel that part of the reason why librarians know less (pedagogically) about teaching than their fellow faculty is because library science graduate programs do not aptly prepare librarians for that 
facet of their role, which for many graduate students becomes a large part of their future professional activities (Partello, 2005). One respondent expresses, "For current institutions, there should be professional development (possibly done in-house with outstanding instruction librarians) to help develop effective teaching methods no matter what the context, and professional development (and the related time) devoted to crafting meaningful curriculum, in collaboration with faculty for integrated sessions or through assessing the general needs of students and the most effective methods for instruction."

Lack of preparation relating to teaching, confusion over professional identity, and nontraditional models of teaching may account for some of the differences among librarians' reasons for identifying themselves (or not) as teachers.

\section{Political Importance of IL Instruction}

Based on the survey results, librarians believe that teaching IL on campus is politically important to the library, regardless of the instruction model used. Among survey respondents, $78.4 \%$ of those who only taught course-integrated sessions either agree or strongly agree with the statement, "Course-integrated information literacy courses are politically important to the standing and reputation of the library on campus." Of that same group, 16.4\% remained neutral, while only $5.3 \%$ of respondents disagree or strongly disagree with that statement. Similarly, of those who teach both for-credit and course-integrated sessions, $80.9 \%$ of librarians either agree or strongly agree with the same statement, while $11.0 \%$ of respondents are neutral, and $8.2 \%$ either disagree or strongly disagree (see Table 5). As one survey respondent indicates, "In my mind, there is no doubt that institutional support of information literacy instruction is paramount to its success, in either course-integrated or for-credit formats."

\begin{tabular}{|l|l|l|l|l|l|}
\hline $\begin{array}{l}\text { Table 5. Political Importance of IL } \\
\text { Instruction }\end{array}$ & $\begin{array}{l}\text { Strongly } \\
\text { Disagree }\end{array}$ & Disagree & Neutral & Agree & $\begin{array}{c}\text { Strongly } \\
\text { Agree }\end{array}$ \\
$\begin{array}{l}\text { Statement: } \\
\text { "Course-integrated information } \\
\text { literacy courses are politically } \\
\text { important to the standing and } \\
\text { reputation of the library on }\end{array}$ & & & & & \\
\hline
\end{tabular}




\begin{tabular}{|l|l|l|l|l|l|}
\hline campus." & & & & & \\
\hline Librarians who teach both & $1.4 \%$ & $6.8 \%$ & $11.0 \%$ & $52.1 \%$ & $28.8 \%$ \\
\hline $\begin{array}{l}\text { Librarians who teach only course- } \\
\text { integrated }\end{array}$ & $1.2 \%$ & $4.1 \%$ & $16.4 \%$ & $46.2 \%$ & $32.2 \%$ \\
\hline
\end{tabular}

When asked about the political importance of for-credit courses, $72 \%$ of those who teach both for-credit and course-integrated sessions either agree or strongly agree with the statement, "For-credit information literacy courses are politically important to the standing and reputation of the library on campus." In that respondent group $17.3 \%$ remain neutral and $10.7 \%$ either disagree or strongly disagree with that statement (see Table 6). The librarians who teach only course-integrated were not prompted to complete this question since they do not teach forcredit courses. One librarian from this group notes, "The for-credit course has had a tremendous campus-wide impact on the knowledge and use of information resources. I think it is an excellent vehicle for information literacy instruction."

\begin{tabular}{|l|l|l|l|l|c|}
\hline $\begin{array}{l}\text { Table 6. Political Importance of IL } \\
\text { Instruction }\end{array}$ & $\begin{array}{l}\text { Strongly } \\
\text { Disagree }\end{array}$ & Disagree & Neutral & Agree & $\begin{array}{c}\text { Strongly } \\
\text { Agree }\end{array}$ \\
$\begin{array}{l}\text { Statement: } \\
\text { "For-credit information literacy } \\
\text { courses are politically important } \\
\text { to the standing and reputation of } \\
\text { the library on campus." }\end{array}$ & & & & & \\
\hline Librarians who teach both & $6.7 \%$ & $4.0 \%$ & $17.3 \%$ & $44.0 \%$ & $28.0 \%$ \\
\hline
\end{tabular}

There is a slight discrepancy in the attitudes of survey respondents who teach using both models of IL sessions when asked to consider whether for-credit IL courses are politically important to the standing and reputation of the library on campus. The librarians who teach both models of IL instruction believe that course-integrated sessions (80.9\%) are slightly more politically important than for-credit IL courses $(72 \%)$. This discrepancy might indicate that librarians who teach for-credit courses feel more isolated than those who teach courseintegrated IL because faculty may not be aware of them, especially if the class is not tied to a discipline. Since most teaching faculty play at least some role in course-integrated classes, either team-teaching with librarians or consulting with the librarian about the research assignment, more faculty are aware of librarians who follow this approach. Course-integrated library instruction may simply be more visible to non-library faculty on campus. 
Anecdotally, many librarians argue that credit-bearing courses are more valuable politically because they generate tuition credit dollars. Instead, the attitudes expressed in our survey results, suggest that course-integrated classes are more politically important to the library's reputation on campus than for-credit IL courses. Jeanne R. Davidson discusses political importance in her article in which she conducts a survey about librarians' perceptions of the political importance of teaching for-credit courses. $79 \%$ of librarians surveyed felt that teaching credit-bearing courses is politically important. One respondent explained her interpretation of the survey statement this way: "I indicated neutral about embedded IL [courseintegrated classes] being political. In my experience, professors and deans have to [be] convinced that the IL content is relevant and the librarian is skilled at teaching in a postsecondary environment." Like Davidson, we did not define political capital for our respondents, but allowed them to define and interpret for themselves. The notion of political capital on campus can be interpreted in different ways. In future studies, it may be beneficial to require respondents to specifically define and respond to what political importance or political capital means in the context of instruction models. It is interesting to note that the librarians we surveyed who teach both for-credit and course-integrated sessions would not agree that the forcredit model offers unique political capital. Further research is needed exploring how librarians define political capital. Discussions of this nature have largely been anecdotal in the past. Understanding how perceived institutional support affect how librarians make instructional decisions warrants further exploration.

\section{Effectiveness of IL Models}

While many librarians remain neutral on the subject (54.2\% of all respondents), the survey indicates that librarians who teach both models of IL instruction are more likely to favor the effectiveness of for-credit courses over course-integrated instruction. Among survey respondents who teach with both models, $58.7 \%$ either agree or strongly agree with the following statement: "I find for-credit information literacy courses more effective than courseintegrated information literacy sessions" (see Table 7). However, only 14.4\% of librarians who teach only course-integrated sessions agree or strongly agree with this statement. This indicates that librarians who teach both models slightly favor for-credit classes, while those who only teach course-integrated do not. While $64.1 \%$ of librarians who teach only course-integrated 
remain neutral on this topic, this most likely reflects the fact that these teachers don't have experience with for-credit instruction and do not feel qualified to make a judgment on which model is more effective.

\begin{tabular}{|c|c|c|c|c|c|}
\hline $\begin{array}{l}\text { Table 7. Effectiveness of IL Models } \\
\text { Statement: } \\
\text { "I find for-credit information } \\
\text { literacy courses more effective than } \\
\text { course-integrated information } \\
\text { literacy sessions." }\end{array}$ & $\begin{array}{l}\text { Strongly } \\
\text { Disagree }\end{array}$ & Disagree & Neutral & Agree & $\begin{array}{c}\text { Strongly } \\
\text { Agree }\end{array}$ \\
\hline Librarians who teach both & $0 \%$ & $6.7 \%$ & $34.7 \%$ & $36.0 \%$ & $22.7 \%$ \\
\hline $\begin{array}{l}\text { Librarians who teach only course- } \\
\text { integrated }\end{array}$ & $5.9 \%$ & $15.7 \%$ & $64.1 \%$ & $8.5 \%$ & $5.9 \%$ \\
\hline
\end{tabular}

Similarly, course-integrated only library instructors are slightly more likely to agree or strongly agree $(85.4 \%)$ with the following statement than their counterparts who teach both $(74.3 \%)$ : "The most effective information literacy teaching model integrates instruction throughout students' coursework, preferably beginning with course-integrated information literacy sessions in composition classes and ending with information literacy instruction in capstone courses" (see Table 8).

\begin{tabular}{|c|c|c|c|c|c|}
\hline $\begin{array}{l}\text { Table 8. Effectiveness of IL } \\
\text { Models } \\
\text { Statement: } \\
\text { "The most effective information } \\
\text { literacy teaching model } \\
\text { integrates instruction } \\
\text { throughout students' } \\
\text { coursework, preferably } \\
\text { beginning with course-integrated } \\
\text { information literacy sessions in } \\
\text { composition classes and ending } \\
\text { with information literacy } \\
\text { instruction in capstone courses." }\end{array}$ & $\begin{array}{l}\text { Strongly } \\
\text { Disagree }\end{array}$ & Disagree & Neutral & Agree & $\begin{array}{c}\text { Strongly } \\
\text { Agree }\end{array}$ \\
\hline Librarians who teach both & $0.0 \%$ & $1.4 \%$ & $20.3 \%$ & $35.1 \%$ & $39.2 \%$ \\
\hline $\begin{array}{l}\text { Librarians who teach only course- } \\
\text { integrated }\end{array}$ & $0.0 \%$ & $4.1 \%$ & $10.5 \%$ & $37.4 \%$ & $48.0 \%$ \\
\hline
\end{tabular}


These results imply that librarians who teach only course-integrated classes prefer the courseintegrated style to those who teach with both models of IL instruction. One of the respondents from this section indicates, "I think that course-integrated instruction can be very effective. An advantage to them is the audience is very motivated and receptive to what you say because it refers to specific assignments that students have."

While it might be expected that course-integrated only instructors would prefer their own style, the difference in their perception of for-credit courses is interesting when compared to librarians who teach both. Among librarians who teach both, 58.7\% think for-credit courses are more effective than course-integrated sessions, while $14.4 \%$ of course-integrated only instructors agree. This discrepancy likely speaks to a bias for one's own experience. Often when an academic library is an advocate of one type of IL instruction, its librarians will support that model wholeheartedly, especially if it's the only type of instruction they know.

The majority of librarians who teach using both models appear to favor for-credit, however, and this opinion might hold more weight since it comes from librarians who have experience with both types of instruction. As a survey respondent expresses, "Both are an important component of a student's education, and when combined the student is well prepared for college level research projects. A for-credit course is longer though, and can cover areas that extend beyond an immediate assignment and have a high level of value for long-term instruction for a student."

\section{Conclusion and Recommendations}

This study begins to explore the relationship between librarians' self-identification as teachers and their views on the effectiveness of two models of instruction: for-credit courses and courseintegrated library instruction. Current literature extensively discusses the benefits, challenges, programmatic approaches and practical implementation of both models. However, there is little evidence about why, or if, librarians prefer one model over the other and how this relates to teacher self-identification. Included in this discussion are IL instructors' perceptions of how important each model is to the library's political standing at their institutions. Both issues probe why and how librarians make decisions regarding instruction, particularly relating to why 
they choose a specific instruction model. It may be that institutional support, or at least perceived support, may be related to the model employed.

This study indicates that there is an important relationship between IL instruction models employed and the ways in which librarians identify themselves as teachers. Currently, fewer instruction librarians, as indicated by the respondents to our survey, have had the opportunity to try using both models. Nearly all (except for the 6 respondents who taught only for-credit) of the respondents who completed the survey had some experience teaching with the course-integrated model, but fewer (only 27\%) had experience teaching for-credit courses. As more opportunities become available to library instructors, it is expected that views on the effectiveness of the available instruction models and on their own roles as teachers will change. The authors by no means believe that one model must be declared as "the most effective." Instead, we recognize the important possibilities of hybrid models and of extracting the most useful strategies from each to meet the needs of individual classes and students.

Important questions remain. To what degree are faculty and students at various institutions aware of IL and how it is being taught on their campus? What are the perceptions of faculty regarding the teaching abilities of librarians and how does this affect the way librarians see themselves? What do all of these questions say about why librarians choose a particular instruction model? Motivations may include learning theory, experience, institutional tradition, perceived support of the institution, or likely, a combination of factors. These issues are central to conversations about librarians' ability to be effective in the classroom, and they deserve further consideration. This study begins to identify trends in motivation for decisions about IL models. The findings suggest that we need to better understand how and why librarians make decisions, especially with constrained budgets and scarce human resources. One possible direction for future research includes asking instruction coordinators, who are instrumental in the decision making process, to respond to these survey findings. By doing so, a larger picture programmatically of the motivations for instructional decisions may be acquired, along with a better understanding of how our motivations impact student learning. 


\section{References}

Atkins, S.E. (2003), The Academic Library in the American University, UW-Madison Libraries Parallel Press, Madison, WI.

Auer, N.J. and Krupar, E.M. (2005), “Librarians grading: giving a's, b's, c's, d's, and f's”, The Reference Librarian, Vol. 43 No. 89, p. 39.

Badke, W. (2008), “Ten reasons to teach information literacy for credit”, Online, Vol. 32 No. 6, pp. 47-49.

Bell, S. (2008), "IL course credit does not equal credibility", available at: http://acrlog.org/2008/11/25/il-course-credit-does-not-equal-credibility/ (accessed March 28, 2011).

Bordonaro, K. and Richardson, G. (2004), "Scaffolding and reflection in course-integrated library instruction", Journal of Academic Librarianship, Vol. 30 No. 5, pp. 391-401.

Burkhardt, J.M. (2007),“Assessing library skills: a first step to information literacy”, portal: Libraries and the Academy, Vol. 7 No. 1, pp. 25-49.

Douglas, G.V. (1999), "Professor librarian: a model of the teaching librarian of the future", Computers in Libraries, Vol. 19 No. 10, pp. 24-30.

Jacobson, T. and Mark, B.L. (2000), "Separating wheat from chaff: helping first-year students become information savvy", The Journal of General Education, Vol. 49 No. 4, pp. 256278.

Kemp, J. (2006), "Isn't being a librarian enough? -- librarians as classroom teachers", College \& Undergraduate Libraries, Vol. 13 No. 3, p. 3.

Kobzina, N.G. (2010),“A faculty-librarian partnership: a unique opportunity for course integration”, Journal of Library Administration, Vol. 50 No. 4, p. 293.

Saunders, L. (2008), "The future of information literacy in academic libraries: a Delphi study", portal: Libraries and the Academy, Vol. 9 No. 1, pp. 99-114.

Lindstrom, J. and Shonrock, D.D. (2006), "Faculty-librarian collaboration to achieve integration of information literacy”, Reference \& User Services Quarterly, Vol. 46 No. 1, pp. 18-23.

MacDonald, M.C., Rathemacher, A.J. and Burkhardt, J.M. (2000), “Challenges in building an incremental, multi-year information literacy plan”, Reference Services Review, Vol. 28 No. 3, pp. 240-247.

Smale, M. (2010), "Staying the course”, available at: http://acrlog.org/2010/02/01/staying-thecourse/ (accessed March 28, 2011).

Owusu-Ansah, E.K. (2004), “Information literacy and higher education: placing the academic library in the center of a comprehensive solution", Journal of Academic Librarianship, 
Vol. 30 No. 1, pp.3-16.

Partello, P. (2005), “Librarians in the classroom”, The Reference Librarian, Vol. 43 No. 89, p. 107.

Pickard, A. (2007), Research Methods in Information, Facet Publishing, London, England.

Walter, S. (2008), "Librarians as teachers: a qualitative inquiry into professional identity," College \& Research LibrariesVol. 69, No. 1 p. 52.

Winner, M.C. (1998), "Librarians as partners in the classroom: an increasing imperative", Reference Services Review, Vol. 26 No. 1, pp. 25-30. 
Appendix A: Everyone Answers

\begin{tabular}{|l|c|c|c|c|c|}
\hline & $\begin{array}{l}\text { Strongly } \\
\text { Disagree }\end{array}$ & Disagree & Neutral & Agree & $\begin{array}{l}\text { Strongly } \\
\text { Agree }\end{array}$ \\
\hline I consider myself a teacher. & $1.2 \%$ & $5.3 \%$ & $10.2 \%$ & $42.3 \%$ & $41.1 \%$ \\
\hline I consider myself a librarian. & $0.4 \%$ & $0.0 \%$ & $0.8 \%$ & $24.3 \%$ & $74.5 \%$ \\
\hline $\begin{array}{l}\text { I believe students find for-credit } \\
\text { information literacy courses more } \\
\text { effective than course-integrated } \\
\text { information literacy sessions. }\end{array}$ & $3.7 \%$ & $11.2 \%$ & $58.5 \%$ & $17.8 \%$ & $8.7 \%$ \\
\hline $\begin{array}{l}\text { I find for-credit information } \\
\text { literacy courses more effective } \\
\text { than course-integrated } \\
\text { information literacy sessions. }\end{array}$ & $3.8 \%$ & $12.1 \%$ & $54.2 \%$ & $17.9 \%$ & $12.1 \%$ \\
\hline $\begin{array}{l}\text { I feel supported by library } \\
\text { administration in my } \\
\text { information literacy teaching } \\
\text { endeavors. }\end{array}$ & $2.9 \%$ & $6.1 \%$ & $8.6 \%$ & $44.9 \%$ & $37.6 \%$ \\
\hline $\begin{array}{l}\text { I feel supported by my } \\
\text { colleagues in my information } \\
\text { literacy teaching endeavors. }\end{array}$ & $1.2 \%$ & $3.3 \%$ & $6.1 \%$ & $50.8 \%$ & $38.5 \%$ \\
\hline $\begin{array}{l}\text { I consider myself as much of a } \\
\text { teacher as the professors who } \\
\text { teach outside the library. }\end{array}$ & $4.9 \%$ & $18.7 \%$ & $19.5 \%$ & $26.4 \%$ & $30.5 \%$ \\
\hline
\end{tabular}


Appendix B: "I Only Teach Course-Integrated" Section

\begin{tabular}{|l|c|l|l|l|l|}
\hline & $\begin{array}{l}\text { Strongly } \\
\text { Disagree }\end{array}$ & Disagree & Neutral & Agree & $\begin{array}{c}\text { Strongly } \\
\text { Agree }\end{array}$ \\
\hline $\begin{array}{l}\text { I enjoy teaching course- } \\
\text { integrated information literacy } \\
\text { sessions. }\end{array}$ & $0.0 \%$ & $5.2 \%$ & $4.0 \%$ & $34.1 \%$ & $56.1 \%$ \\
\hline $\begin{array}{l}\text { I believe my students enjoy } \\
\text { taking course-integrated } \\
\text { information literacy sessions. }\end{array}$ & $2.3 \%$ & $11.0 \%$ & $39.9 \%$ & $38.2 \%$ & $8.7 \%$ \\
\hline $\begin{array}{l}\text { Students in course-integrated } \\
\text { information literacy sessions are } \\
\text { apathetic, viewing them as either } \\
\text { boring guest lectures or busy } \\
\text { work. }\end{array}$ & $4.1 \%$ & $36.6 \%$ & $31.4 \%$ & $25.6 \%$ & $2.3 \%$ \\
\hline $\begin{array}{l}\text { I believe course-integrated } \\
\text { information literacy sessions are } \\
\text { conducive to student learning. }\end{array}$ & $0.0 \%$ & $2.9 \%$ & $9.9 \%$ & $56.1 \%$ & $31.0 \%$ \\
\hline $\begin{array}{l}\text { Course-integrated information } \\
\text { literacy courses are politically } \\
\text { important to the standing and } \\
\text { reputation of the library on } \\
\text { campus. }\end{array}$ & $1.2 \%$ & $4.1 \%$ & $16.4 \%$ & $46.2 \%$ & $32.2 \%$ \\
\hline $\begin{array}{l}\text { Course-integrated information } \\
\text { literacy courses provide better } \\
\text { opportunities for librarians to } \\
\text { build lasting relationships with } \\
\text { students than for-credit courses. }\end{array}$ & $6.4 \%$ & $23.4 \%$ & $39.8 \%$ & $18.1 \%$ & $12.3 \%$ \\
\hline $\begin{array}{l}\text { The complexity of the current } \\
\text { information environment } \\
\text { necessitates course-integrated } \\
\text { information literacy sessions. }\end{array}$ & $1.2 \%$ & $8.1 \%$ & $15.1 \%$ & $41.3 \%$ & $34.3 \%$ \\
\hline $\begin{array}{l}\text { The most effective information } \\
\text { literacy teaching model } \\
\text { integrates instruction throughout } \\
\text { students' coursework, preferable } \\
\text { beginning with course-integrated } \\
\text { information literacy sessions in } \\
\text { composition classes and ending } \\
\text { with information literacy } \\
\text { instruction in capstone courses. }\end{array}$ & $0.0 \%$ & $4.1 \%$ & $10.5 \%$ & $37.4 \%$ & $48.0 \%$ \\
\hline & & & & & \\
\end{tabular}




\section{Appendix C: “I Teach Both” (For-Credit related questions)}

\begin{tabular}{|l|c|c|c|c|c|}
\hline & $\begin{array}{l}\text { Strongly } \\
\text { Disagree }\end{array}$ & Disagree & Neutral & Agree & $\begin{array}{c}\text { Strongly } \\
\text { Agree }\end{array}$ \\
\hline $\begin{array}{l}\text { I enjoy teaching for-credit } \\
\text { information literacy courses. }\end{array}$ & $0.0 \%$ & $1.3 \%$ & $5.3 \%$ & $36.0 \%$ & $57.3 \%$ \\
\hline $\begin{array}{l}\text { I believe my students enjoy } \\
\text { taking for-credit information } \\
\text { literacy courses. }\end{array}$ & $1.3 \%$ & $9.3 \%$ & $36.0 \%$ & $42.7 \%$ & $10.7 \%$ \\
\hline $\begin{array}{l}\text { Students in for-credit information } \\
\text { literacy courses are apathetic, } \\
\text { viewing the classes as just another } \\
\text { requirement for graduation. }\end{array}$ & $6.8 \%$ & $33.8 \%$ & $39.2 \%$ & $14.9 \%$ & $5.4 \%$ \\
\hline $\begin{array}{l}\text { I believe for-credit information } \\
\text { literacy courses are conducive to } \\
\text { students learning }\end{array}$ & $0.0 \%$ & $0.0 \%$ & $9.5 \%$ & $44.6 \%$ & $45.9 \%$ \\
\hline $\begin{array}{l}\text { For-credit information literacy } \\
\text { courses are politically important } \\
\text { to the standing and reputation of } \\
\text { the library on campus. }\end{array}$ & $6.7 \%$ & $4.0 \%$ & $17.3 \%$ & $44.0 \%$ & $28.0 \%$ \\
\hline $\begin{array}{l}\text { For-credit information literacy } \\
\text { courses provide better } \\
\text { opportunities for librarians to } \\
\text { build lasting relationships with } \\
\text { students than course-integrated } \\
\text { sessions. }\end{array}$ & $1.4 \%$ & $4.1 \%$ & $8.1 \%$ & $37.8 \%$ & $48.6 \%$ \\
\hline $\begin{array}{l}\text { The complexity of the current } \\
\text { information environment } \\
\text { necessitates for-credit } \\
\text { information literacy courses. }\end{array}$ & $1.3 \%$ & $2.7 \%$ & $24.0 \%$ & $37.3 \%$ & $34.7 \%$ \\
\hline
\end{tabular}


Appendix D: "I Teach Both" (Course-Integrated related questions)

\begin{tabular}{|l|c|l|l|l|l|}
\hline & $\begin{array}{l}\text { Strongly } \\
\text { Disagree }\end{array}$ & Disagree & Neutral & Agree & $\begin{array}{c}\text { Strongly } \\
\text { Agree }\end{array}$ \\
\hline $\begin{array}{l}\text { I enjoy teaching course- } \\
\text { integrated information literacy } \\
\text { sessions. }\end{array}$ & $0.0 \%$ & $2.6 \%$ & $5.3 \%$ & $55.3 \%$ & $36.8 \%$ \\
\hline $\begin{array}{l}\text { I believe my students enjoy } \\
\text { taking course-integrated } \\
\text { information literacy sessions. }\end{array}$ & $1.3 \%$ & $10.5 \%$ & $46.1 \%$ & $35.5 \%$ & $6.6 \%$ \\
\hline $\begin{array}{l}\text { Students in course-integrated } \\
\text { information literacy sessions are } \\
\text { apathetic, viewing them as either } \\
\text { boring guest lectures or busy } \\
\text { work. }\end{array}$ & $4.0 \%$ & $28.0 \%$ & $50.7 \%$ & $13.3 \%$ & $4.0 \%$ \\
\hline $\begin{array}{l}\text { I believe course-integrated } \\
\text { information literacy sessions are } \\
\text { conducive to student learning. }\end{array}$ & $0.0 \%$ & $0.0 \%$ & $17.6 \%$ & $54.1 \%$ & $28.4 \%$ \\
\hline $\begin{array}{l}\text { Course-integrated information } \\
\text { literacy courses are politically } \\
\text { important to the standing and } \\
\text { reputation of the library on } \\
\text { campus. }\end{array}$ & $1.4 \%$ & $6.8 \%$ & $11.0 \%$ & $52.1 \%$ & $28.8 \%$ \\
\hline $\begin{array}{l}\text { Course-integrated information } \\
\text { literacy courses provide better } \\
\text { opportunities for librarians to } \\
\text { build lasting relationships with } \\
\text { students than for-credit courses. }\end{array}$ & $11.0 \%$ & $35.6 \%$ & $21.9 \%$ & $12.3 \%$ & $19.2 \%$ \\
\hline $\begin{array}{l}\text { The complexity of the current } \\
\text { information environment } \\
\text { necessitates course-integrated } \\
\text { information literacy sessions. }\end{array}$ & $0.0 \%$ & $1.4 \%$ & $12.7 \%$ & $54.9 \%$ & $31.0 \%$ \\
\hline $\begin{array}{l}\text { The most effective information } \\
\text { literacy teaching model } \\
\text { integrates instruction throughout } \\
\text { students' coursework, preferable } \\
\text { beginning with course-integrated } \\
\text { information literacy sessions in } \\
\text { composition classes and ending } \\
\text { with information literacy } \\
\text { instruction in capstone courses. }\end{array}$ & $0.0 \%$ & $5.4 \%$ & $20.3 \%$ & $35.1 \%$ & $39.2 \%$ \\
\hline & & & & & \\
\hline
\end{tabular}

(1)Number is approximated due to slight variation in answers within this group for specific questions. Response rate varied from $240-247$. 